Danuta Apanel

(Stupsk)

\title{
Rola instytucji pozarządowych w opiece nad dzieckiem na Pomorzu Środkowym w latach 1945-1975 - zarys problemu
}

\begin{abstract}
Wstęp
Rozwój opieki nad dzieckiem w pierwszym trzydziestoleciu po II wojnie światowej na tle polityki opiekuńczej państwa można podzielić na kilka charakterystycznych okresów.

Pierwszy z nich obejmuje lata 1945-1949 i określany jest mianem ratownictwa, kolejny - lata 1950-1955, zwany jest okresem centralizacji działalności, okres zamknięty ramami lat 1956-1970 to okres tworzenia nowych podstaw teoretycznych i instytucjonalnych opieki wychowawczej oraz nawiązywania do sprawdzonego już dorobku przeszłości, następny - obejmujący lata 1971-1980 był okresem modernizacji w opiece nad dzieckiem.

$\mathrm{Na}$ tym tle rozpatrywać można działalność instytucji pozarządowych w opiece nad dzieckiem, która dzieli się na wyraźne etapy. Etap pierwszy - do 1950 roku, etap drugi - okres od 1950 roku do czasu przemian ustrojowych.

W prezentowanym opracowaniu w zarysie przedstawiona zostanie działalność instytucji pozarządowych w pierwszym i drugim etapie. Jest to problem bardzo obszerny, wymagający wciąż głębokiej analizy i wnikliwych badań.

Ramy czasowe obejmujące analizowany problem, tj. lata 1945-1975 wyznaczony został nieprzypadkowo, gdyż pierwsza $z$ dat związana jest ze zmianą sytuacji w opiece nad człowiekiem po zakończeniu działań wojennych, druga związana jest ze zmianą w problemach opieki na skutek reformy administracyjnej kraju. Do 1975 r. teren Pomorza Środkowego pokrywał się praktycznie z terenem ówczesnego województwa koszalińskiego, co niewątpliwie miało również znaczenie dla działań podejmowanych przez instytucje pozarządowe.
\end{abstract}




\section{Działalność instytucji pozarządowych w opiece nad dzieckiem w pierwszych latach po II wojnie światowej - zarys problemu}

Wojna i okupacja spowodowały zagrożenie biologiczne bytu naszego narodu. W tym okresie zginęło ponad 2225000 dzieci i młodzieży, co stanowiło około 35\% ogólnych strat ludnościowych poniesionych przez Polskę .

Powstałe w lutym 1945 r. Biuro Informacji i Poszukiwań PCK już w ciągu pierwszych 11 miesięcy działalności posiadało w swej kartotece 270 tys. wniosków o poszukiwanie zaginionych, w tym także dzieci.

Poważnym problemem było rozproszenie rodzin jako rezultat intencjonalnej działalności okupanta, ale również masowych przesiedleń, migracji i działań wojennych. Dziecko żyjące przez kilka lat w poczuciu ciągłego zagrożenia, pozbawione możliwości normalnego rozwoju było najpilniejszym i niezmiernie trudnym podmiotem działań opiekuńczych. Stan zdrowia dzieci był katastrofalny wskutek wyjątkowo ciężkich warunków materialnych i braku opieki lekarskiej².

Dziecko trafiające wówczas do placówki opieki zastępczej to najczęściej powojenny rozbitek, bezdomny włóczęga, który przewędrowat Polskę wzdluż $i$ wszerz $w$ poszukiwaniu rodziny i przygody; element to lotny, burzliwy i zuchwaty. Nierzadko byli to uczestnicy walk partyzanckich, powstania, więźniowie obozów koncentracyjnych, świadkowie najpotworniejszych scen wojennych. Nie pozwalali się traktować jak dzieci. Dziecięctwo swe bowiem pozostawili $w$ zgliszczach domów rodzinnych ${ }^{3}$.

W wyniku wojny sprawa sieroctwa i wyrównywania jego skutków urosła do rozmiarów jednego z najważniejszych zagadnień społecznych ${ }^{4}$.

Znaczny wkład w rozwiązywanie problemów nad dziećmi osamotnionymi wniosły organizacje społeczne: Robotnicze Towarzystwo Przyjaciół Dzieci, Chłopskie Towarzystwo Przyjaciół Dzieci, Centralny Komitet Opieki Społecznej, Polski Czerwony Krzyż, Caritas. W omawianym okresie, państwo nie było jeszcze głównym i jedynym organizatorem opieki nad dzieckiem. Wiele organizacji prowadziło swoje placówki - domy dziecka, zakłady wychowawcze, świetlice, żłobki, przedszkola, prewentoria, a także podejmowało różne akcje, np. związane z organizacją kolonii letnich.

Robotnicze Towarzystwo Przyjaciół Dzieci prowadziło na terenie całego kraju w 1947 r. 240 instytucji wychowawczych dla 40 tys. dzieci, w tym domy dziecka (23), przedszkola, świetlice, poradnie lecznicze i wychowawcze, a nawet teatry dla dzieci ${ }^{5}$.

Taką samą działalność na terenie wsi prowadziło Chłopskie Towarzystwo Przyjaciół Dzieci, powołane do życia pod koniec 1945 r. z inicjatywy Związku Młodzieży Wiej-

\footnotetext{
${ }^{1}$ O. Terlecki, Najkrótsza historia drugiej wojny światowej, Kraków-Wrocław 1984, s. 18.

2 Zagrożone dzieciństwo. Rodzinne i instytucjonalne formy opieki, red. M. Kolankiewicz, Warszawa 1998, s. 10 .

${ }^{3}$ H. Wolawska, Pogotowie opiekuńcze w Sopocie, „Dzieci i Wychowawca” 1950, nr 3.

${ }^{4}$ J. Wojtyniak, Badania nad zasięgiem sieroctwa, w: J. Wojtyniak, H. Radlińska, Sieroctwo. Zasięg $i$ wyrównanie, Polski Instytut Służby Społecznej, Łódź 1946.

${ }^{5}$ RTPD, „Dzieci i Wychowawca” 1947, nr 1-2, s. 48-50.
} 
skiej R.P. „Wici”. Koncentrowało ono swą uwagę na opiece zdrowotnej, wychowawczej $i$ kulturalnej nad dzieckiem chłopskim od niemowlęctwa do lat $16^{6}$.

$\mathrm{Na}$ uwagę zasługuje niewątpliwie Caritas - organizacja reprezentująca dobroczynną i społeczno-opiekuńczą działalność Kościoła katolickiego. Można wyróżnić trzy sfery w działalności Caritasu po wojnie ${ }^{7}$ :

- doraźna pomoc ofiarom wojny (kuchnie, rozdawnictwo odzieży, zapomogi pieniężne), a także pomoc ludności polskiej w okresie jej migracji - powrót z wysiedlenia, repatriacja z zachodu i wschodu (izby dworcowe, schroniska i domy noclegowe, kuchnie),

- walka o życie i zdrowie dzieci (prewentoria dla dzieci zagrożonych gruźlicą, masowe badania rentgenowskie wśród dzieci, pomoc dla dzieci upośledzonych),

- opieka nad sierotami i dziećmi opuszczonymi.

Pomoc Caritasu była całkowita (domy dziecka, zakłady wychowawcze), albo częściowa (ochronki, żłobki, przedszkola, świetlice, stacje opieki nad matką i dzieckiem, kolonie i półkolonie), albo doraźna - przez misje dworcowe, pomoc lekarską, odzieżową i żywnościową.

W liczbach w 1946 r. pomoc ta w skali kraju wyglądała następująco: 751 zakładów opieki całkowitej (27 żłobków, 22 zakłady mieszane dla dzieci i dorosłych, 183 domy dziecka, 125 internatów, 5 zakładów specjalnych), 1023 zakłady opieki częściowej (151 kuchni ludowych punktów dożywiania dzieci, 743 ochronki i przedszkola, 13 poradni dla matki i dziecka, 25 świetlic, 3 żłobki dzienne). W sumie pod opieką Caritasu pozostawało ponad 216 tys. dzieci ${ }^{8}$.

Po II wojnie światowej na teren Ziem Odzyskanych, do którego zaliczano również Pomorze Środkowe, przybyła ludność zza Buga, częściowo repatrianci z Zachodu oraz osiedleńcy z Centrum Polski. [...] 60\% tej ludności - jak oświadczono oficjalnie na zebraniu Wojewódzkiego Komitetu Pomocy Zimowej w Szczecinie jesienią 1945 r.: wymaga opieki ze strony państwa, 25\% może się samodzielnie utrzymać, 15\% mogłoby świadczyć na rzecz potrzebujących ${ }^{9}$.

\section{Instytucje pozarządowe w opiece nad dzieckiem na Pomorzu Środkowym}

Życie Polaków na Pomorzu Środkowym zaczęło się organizować znacznie później niż na innych terenach, które po II wojnie światowej wróciły do Polski. Stąd i przejęcie opieki od władz wojewódzkich nastąpiło później niż w innych okręgach szkolnych, a co za tym idzie i organizacja Wydziału Opieki nad Dzieckiem w Kuratorium oraz Referatów

${ }^{6}$ ChTPD, „Dzieci i Wychowawca” 1947, nr 5-6, s. 87-89.

7 Kronika, „Dzieci i Wychowawca” 1974, nr 11-12, s. 75-78.

8 S. Lisowski, Metody działalności karytatywnej. Analiza zagadnienia na tle działalności Caritasu w Polsce w latach 1945-1950, „Studia Teologiczne” 1976, s. 213-229.

9 WAP w Szczecinie, Zespół Akt Kuratorium Okręgu Szkolnego Szczecińskiego, J. Kania, Sprawozdanie na temat funkcjonowania systemu szkolnego $w$ województwie szczecinskim $w$ pierwszych latach po II wojnie światowej, sygn. 4571. 
w Inspektoratach Szkolnych pozostawała $w$ tyle o dobrych kilka miesięcy $w$ porównaniu z innymi okręgami szkolnymi ${ }^{10}$. Powstające wówczas wszelkiego rodzaju placówki opiekuńcze przychodzity z pomoca materialna każdemu, kto o te pomoc się ubiegat, nie analizując, czy rzeczywiście należało przyjść z pomoca czy té̇ odmówić11.

W sprawozdaniu Wydziału Opieki nad Dzieckiem w WAP w Szczecinie z 1945 r. czytamy: Opieka nad dzieckiem w Okręgu Szkolnym Szczecińskim jest dopiero w stanie organizacji. Ten etap potrwa jeszcze rok. Nie zakończyt sie jeszcze proces zasiedlania. Wiosna zaczna naptywać repatrianci. Ma ich przybyć pół miliona. Nie trudno odgadnać, że będa to dzieci wynędzniałe, anemiczne, skłonne do różnych chorób, źle odżywione, źle ubrane, bose. Będa one potrzebowaty wszechstronnej opieki i pomocy ze strony państwa $a^{12}$.

Prace częściowo zorganizowanych Komitetów Opieki Społecznej, kierowanych przez zorganizowany w kwietniu 1945 r. Wojewódzki Komitet Opieki Społecznej polegały na poszukiwaniu dzieci polskich zaginionych w transportach repatriantów, wywożonych do Niemiec lub napływających ze Wschodu i umieszczaniu ich w różnych placówkach opiekuńczo-wychowawczych na terenie Pomorza Środkowego. W tym okresie tzw. instytucje opieki dobrowolnej znajdowały się w stadium organizacji. Działalność związaną z opieką nad dziećmi i młodzieżą Kuratorium przejęło od Wydziału Wojewódzkiego Opieki Społecznej z dniem 1 kwietnia 1946 r.

Organizowanie szkolnictwa oraz systemu opieki i wychowania dzieci i młodzieży w Koszalińskiem prowadzone było równolegle z akcją osiedleńczą, z zagospodarowywaniem tych ziem oraz pracą nad organizowaniem administracji cywilnej. Przygotowania rozpoczęły się jeszcze przed zakończeniem wojny.

Pierwsza faza opieki nad matką i dzieckiem na terenie Pomorza Środkowego przypadała na rok 1945 i pierwsze półrocze 1946 r., i miała charakter improwizacyjny, taki, jak zycie społeczeństwa Pomorza ${ }^{13}$.

Najszerzej zakrojoną działalność w zakresie opieki nad dzieckiem prowadziły tu: Robotnicze Towarzystwo Przyjaciół Dzieci oraz Chłopskie Towarzystwo Przyjaciół Dzieci. Pierwsze ogniwa RTPD na Ziemi Koszalińskiej powstały w końcu 1945 r. w Słupsku, Koszalinie i Szczecinku. W innych miastach odziały RTPD zawiązały się o rok później.

Inspiratorami powołania Miejsko-Powiatowego Oddziału RTPD w Koszalinie w dniu 3 kwietnia 1946 r. byli: Teofil Krzynowek, Czesław Mikołajczyk, Joachim Godek oraz Klaudiusz Górski. W pozostałych oddziałach organizatorami RTPD byli: w Białogardzie - Antoni Jaciubek, w Słupsku - Bolesław Wyszyński, w Szczecinku - Jan Szatkowski.

Obok RTPD w 1946 r. powstawały Oddziały Chłopskiego Towarzystwa Przyjaciół Dzieci. W powiecie Białogard kierował nimi Wincenty Parański, a w powiecie Słupsk

${ }^{10}$ Ibidem, s. 6-7.

11 WAP w Szczecinie, Zespół Akt Kuratorium Okręgu Szkolnego Koszalińskiego, Zbiorcze i jednostkowe plany gospodarcze $w$ zakresie opieki nad dzieckiem, s. 4569.

12 WAP w Szczecinie, J. Kania, Sprawozdanie.

13 Ibidem, s. 4 
- Włodzimierz Rogoziński. Oddział ChTPD w Słupsku był organizatorem Prewentorium Przeciwgruźliczego dla 40 dziewcząt i 40 chłopców w wieku od 7 do 12 lat, które rozpoczęło działalność 1 września 1948 r. Obowiązki kierownika placówki pełnił Antoni Żurawski do czasu przekazania jej pod nadzór Kuratorium Oświaty i Wychowania 19 czerwca $1951 \mathrm{r}$.

Wychodząc naprzeciw pilnym potrzebom w zakresie opieki nad dzieckiem, Oddział RTPD otworzył w Koszalinie na ulicy Fałata 3 Dom Dziecka. Prowadził tę placówkę (później jako oddział TPD) do momentu przejęcia jej przez Kuratorium w dniu 11 października $1951 \mathrm{r}^{14}$

Na terenie Okręgu Koszalińskiego w latach 1946-1949 RTPD i ChTPD opieką obejmowały:

- 768 dzieci w przedszkolach miejskich,

- 612 dzieci w przedszkolach wiejskich,

- 1230 dzieci w świetlicach przyszkolnych,

- 540 dzieci w świetlicach międzyszkolnych,

- 24 dzieci w jednej świetlicy wiejskiej,

- 150 dzieci w jednej bibliotece,

- 90 dzieci w jednym domu dziecka,

- 60 dzieci w jednym internacie,

- 80 dzieci w jednym prewentorium,

- 1967 dzieci w dziewięciu punktach kolonijnych,

- 485 dzieci w siedmiu punktach półkolonijnych,

- 1298 dzieci w 38 dziecińcach wiejskich,

- 327 dzieci na siedmiu wycieczkach dzieci wiejskich,

- 165 dzieci w dziewięciu żłobkach sezonowych ${ }^{15}$.

W maju 1949 r. w wyniku połączenia RTPD i ChTPD powstało Towarzystwo Przyjaciół Dzieci. Już od 1950 r. wskutek odgórnych poleceń, TPD zobowiązane zostało do stopniowego przekazania państwu prowadzonych przez nie placówek higieniczno-lekarskich, opiekuńczo-wychowawczych i oświatowych.

Skuteczną i rozległą działalność na Ziemiach Odzyskanych prowadził Związek „Caritas" Administracji Apostolskiej. Począwszy od 1945 r. instytucja ta na Pomorzu Środkowym posiadała 43 oddziały prowadzące 13 kuchni ludowych, 1 dom noclegowy, 1 szpital (w Trzcinie - pow. Wałcz) oraz warsztaty szkoleniowe. Środki na realizację swoich zamierzeń zdobywała samodzielnie, ponieważ nie korzystała z subwencji państwowych $^{16}$.

\footnotetext{
14 Słowa te pochodzą z wystąpienia długoletniego sekretarza Oddziału Towarzystwa Przyjaciół Dzieci w Koszalinie - Gabriela Bielawowskiego na Wojewódzkim Zjeździe TPD w Koszalinie z okazji 50-lecia działalności na Ziemi Koszalińskiej.

15 Archiwum Towarzystwa Przyjaciół Dzieci w Koszalinie (ATPD w Koszalinie), Dokumentacja walnych zebrań Zarządu RTPD i ChTPD z lat 1946-1949.

${ }^{16}$ Caritas został rozwiązany 31 grudnia 1950 r. przez władze państwowe, a jego majątek przekazano nowej organizacji pod nazwą Zrzeszenie Katolików „C” podporządkowane PZPR. Najdłużej działającym oddziałem Caritasu na Pomorzu Środkowym był oddział w Złotowie przy kościele Najświętszej Marii Panny, którym
} 
Opieką nad dzieckiem i dorosłymi zajmował się również Komitet Pomocy Repatriantom, który rozprowadzał odzież, obuwie, żywność, paczki UNRRA ${ }^{17}$, leki, organizował tymczasowe zakłady opiekuńcze - tzw. Stacje Opieki nad Matką i Dzieckiem.

Pomoc dzieciom i ich rodzinom niosła również Liga Kobiet, która prowadziła Izby Dworcowe, Punkty Opieki nad Matką i Dzieckiem. Środki na prowadzenie tych placówek otrzymywała ze Skarbu Państwa. W okresie Świąt Bożego Narodzenia organizowała tzw. akcje gwiazdkowe - czyli paczki z żywnością i odzieżą dla ubogich dzieci i ich najbliższych. Nadzorowała również pracę żłobków w: Koszalinie, Gryficach, Szczecinie; Izb Dworcowych w: Choszcznie, Białogardzie, Gryficach, Szczecinie, Drawsku, Świnoujściu.

Akcję opiekuńczą na terenie Pomorza Środkowego od momentu ustania działań wojennych prowadził Polski Czerwony Krzyż. Niósł pomoc ofiarom wojny, repatriantom zza Buga, organizował stacje pogotowia ratunkowego, stacje krwiodawstwa, zakłady lecznicze i opiekuńcze, prowadził poszukiwania osób zaginionych i akcję łączenia rodzin, szerzył oświatę zdrowotną.

W dniu 22 czerwca 1945 r. płk Jan Ciałowicz otrzymał nominację na Pełnomocnika Zarządu Głównego PCK. Zachodziła wówczas konieczność organizowania pomocy dla repatriantów z zachodu i wschodu oraz osiedleńców przybywających z centrum kraju. Od 22 czerwca kierował on intensywnymi pracami organizacyjnymi zmierzającymi do pokrycia siecią placówek sanitarnych i opiekuńczych PCK całego Pomorza Zachodniego, a przede wszystkim miast powiatowych, węzłów kolejowych i tych osiedli wiejskich, które ze względu na nasilenie fali osiedleńców wymagały daleko idącej pomocy.

W początkowej fazie Polski Czerwony Krzyż pomagał w ramach repatriacji uregulowanej. Najpierw zajmował się sprawami opiekuńczymi, a później rozwijał lecznictwo. W 1946 r. wspólnie z Komitetem Pomocy Repatriantom i Komitetami Opieki Społecznej rozprowadzit na powiaty $3000 \mathrm{~kg}$ odzieży, $900 \mathrm{~kg}$ obuwia, $50 \mathrm{~kg}$ skarpet, $300 \mathrm{~kg}$ ryżu, 569 paczek UNRRA przybyszom zza Buga i Sybirakom, którzy byli kompletnie wyniszczeni, wycieńczeni, chorzy i niezdolni do pracy. Było wśród nich wielu starców, dużo kalek $i$ sierot ${ }^{18}$. W maju tego roku napływ repatriantów był tak ogromny (po kilka transportów dziennie), że pomoc Polskiego Urzędu Repatriacyjnego, PCK, opieki społecznej okazywała się niewystarczająca.

Pierwsi osiedleńcy kierowani byli do takich powiatów, jak: Stargard, Gryfino, Chojna nad Odrą. W lipcu 1945 r. powstały pierwsze oddziały PCK w Gryfinie i w Stargardzie. Punkt w Gryfinie zorganizował pierwsze w kraju w historii PCK wiejskie stacje sanitarne.

$\mathrm{Na}$ węzłach kolejowych tworzono placówki sanitarno-opiekuńcze, jadłodalnie dla transportów repatriantów. Powstawały nie tylko wiejskie stacje sanitarne, ale także przy-

kierował Klemens Gappa - WAP w Szczecinie, Urząd Wojewódzki w Szczecinie, Sprawozdanie z działalności opieki społecznej 1945-1950, sygn. 4570.

17 Ang. United Nations Relief and Rehabilitation Administration - Organizacja Narodów Zjednoczonych do spraw Pomocy i Odbudowy.

${ }^{18}$ Archiwum Polskiego Czerwonego Krzyża w Koszalinie (APCK w Koszalinie), Sprawozdanie z działalności PCK za lata 1945-1955. 
chodnie lecznicze, domy noclegowe i kuchnie ludowe oraz pierwsze koła grupujące młodzież czerwonokrzyską i starszych. W zakresie opieki nad dziećmi na terenie Pomorza Środkowego do końca 1945 r. PCK utworzyło:

- 7 Stacji Opieki nad Matką i Dzieckiem,

- 9 punktów dożywiania dzieci,

- 5 domów noclegowych,

- 4 kuchnie ludowe.

W Stacjach Opieki nad Matką i Dzieckiem udzielono pomocy i otoczono opieką 2358 osób. Akcją dożywiania objęto 1224 dzieci oraz wydano zapomogi pieniężne w kwocie $31006 \mathrm{zl}^{19}$.

Rok 1946 był najbardziej dynamicznym rokiem w działalności Polskiego Czerwonego Krzyża na Pomorzu Środkowym. Odzwierciedlało się to również w działalności opiekuńczej. Funkcjonowały wówczas:

- 4 Stacje Opieki nad Matką i Dzieckiem,

- 5 schronisk i żłobków (w: Koszalinie, Karlinie, Nowogardzie, Stargardzie i Gryfinie),

- 9 domów noclegowych,

- 6 kuchni ludowych,

- udzielono pomocy odzieżowej 119986 osobom,

- wydano zapomogi pieniężne w kwocie 60710 zł.

W 1947 r. Polski Czerwony Krzyż przekazał część zadań opiekuńczych nowo powstałej organizacji - Komitetowi Opieki Społecznej i rozpoczął szeroką działalność szkoleniową. Do zadań z zakresu opieki nad dziećmi zaliczyć można prowadzenie jednej Stacji Opieki nad Matką i Dzieckiem w Kamieniu Pomorskim.

W porównaniu z rokiem 1946 akcja opiekuńcza straciła znacznie na sile. Złożyła się na to postępująca stabilizacja gospodarcza oraz zmniejszenie napływu ludności. Kuchnie ludowe przygotowywały posiłki dla 43473 osób, wśród których były również dzieci.

Od 1948 r. działalność PCK na Pomorzu można ująć w cztery zasadnicze działy: lecznictwo, opieka społeczna (w ograniczonych rozmiarach - zalecenie rządu), szkolenia sanitarne (szkoły i kursy), ratownictwo (pogotowia ratunkowe i punkty sanitarne). Wówczas na tym terenie istniały 23 oddziały PCK. Prowadzono tylko jedną Stację Opieki nad Matką i Dzieckiem - w Kamieniu Pomorskim. Akcją dożywiania w latach 1948-1949 objęto w kuchniach ludowych 8048 osób, w tym 1981 dzieci. Wydano również zapomogi pieniężne dla 28 rodzin w kwocie $10568 \mathrm{zł}^{20}$.

$\mathrm{Na}$ terenie miast Ziemi Koszalińskiej działały również Towarzystwa Burs i Stypendiów, które udzielały pomocy materialnej (w formie stypendiów) niezamożnej, kształcącej się młodzieży. Organizacja ta liczyła 205 członków, a prezesem jej był Jan Laskowski. Siedziba koszalińskiego Towarzystwa mieściła się przy ul. Armii Czerwonej 37.

Członkowie Towarzystwa zbierali się kilka razy do roku, by rozpatrzyć opisaną w podaniach lub przekazaną ustnie przez nauczycieli sytuację młodych, ambitnych ludzi

\footnotetext{
19 Ibidem.

${ }^{20}$ APCK w Koszalinie, Sprawozdanie.
} 
kształcących się w różnych szkołach średnich na terenie Koszalina (w innych miastach działały odrębne ośrodki Towarzystwa Burs i Stypendiów). Zapomogi w formie stypendiów, miejsc w bursach i internatach przyznawano w pierwszej kolejności młodzieży wywodzącej się z niezamożnych środowisk chłopskich i robotniczych. Środki na pomoc i opiekę organizacja uzyskiwała częściowo z dotacji państwowych, częściowo z zakładów pracy znajdujących się w okolicy lub na terenie miasta.

Wszelkie organizacje istniejące na terenie Pomorza Środkowego wniosły niemały wkład w rozwój opieki nad dzieckiem. W szerokim zakresie wspomagały w działaniach powstające i rozwijające działalność instytucje opieki całkowitej.

Okres od 1950 r. do końca 1955 r. w dziejach powojennej opieki nad dzieckiem określa się mianem centralizacji działalności. Aby zrozumieć zmiany, jakie zaszły wówczas w zakresie opieki, trzeba wspomnieć o przemianach społeczno-politycznych w naszym kraju. Procesy industrializacji, urbanizacji, uspołeczniania rolnictwa rodziły wiele problemów natury opiekuńczej, takich jak: opieka nad dzieckiem obojga rodziców pracujących, pomoc materialna rodzinom wielodzietnym i niepełnym, pomoc w adaptacji rodzinom napływającym do dużych ośrodków przemysłowych.

W swej wypowiedzi na temat planu sześcioletniego zamieszczonej w czasopiśmie Dzieci i Wychowawca Hilary Minc podkreślił: W okresie planu 3-letniego opieka nad dzieckiem prowadzona była nie tylko przez placówki państwowe, ale i przez liczne stowarzyszenia i organizacje społeczne, często niefachowe, $w$ wielu wypadkach również nawet obce pod względem ideologicznym. Świadomi tego stanu $i$ wynikajacych z niego trudności musimy dążć w okresie planu 6-letniego do skupienia dyspozycji akcji opiekuńczo-wychowawczej w ręku państwa. Pozwoli to na planowe, racjonalne wyzyskanie wszystkich środków, roztoczenie właściwego nadzoru i kontroli, a przede wszystkim na realizacje postulatów wychowania socjalistycznego ${ }^{21}$.

W celu ujednolicenia finansowych i programowych podstaw opieki upaństwowiono wszystkie domy dziecka. Rozwiązano wiele stowarzyszeń i organizacji społecznych, w tym m.in. Towarzystwo Przyjaciół Dzieci Ulicy, Towarzystwo Burs i Stypendiów, Towarzystwo Gniazd Sierocych i Wiosek Kościuszkowskich. W 1952 r. przestał działać Polski Instytut Służby Społecznej - niezmiernie ważny ośrodek badawczy w dziedzinie pedagogiki opiekuńczej. Wiele zlikwidowanych instytucji i organizacji miało chlubne tradycje w opiece nad dzieckiem.

Omawiany okres charakteryzowało utrwalanie autorytarnego i totalitarnego ustroju eliminującego wszelkie formy demokracji. Cała pedagogika oparta została na zasadach marksistowskich. W czasopismach dominowały artykuły podkreślające genialność koncepcji pedagogicznej Antoniego Siemionowicza Makarenki, znajdującej szerokie zastosowanie w placówkach opieki nad dzieckiem ${ }^{22}$. „Program” ten miał ułatwić tworzenie materialistycznego poglądu na świat, zwalczanie przejawów religijności dzieci i młodzieży, akcentowanie internacjonalizmu i tzw. socjalistycznego stosunku do pracy i własności społecznej.

21 Ibidem, s. 15.

${ }^{22}$ M.in. W. E. Gmurman, O studiowaniu prac Antoniego Makarenki, „Dom Dziecka” 1955, nr 1, s. 4-22. 
W pierwszych latach omawianego okresu duże znaczenie w organizowaniu systemu opieki nad dzieckiem na Pomorzu Środkowym miała w dalszym ciągu działalność Towarzystwa Przyjaciół Dzieci, które realizowało swoje zadania za pośrednictwem okręgów, oddziałów i kół przyjaciół dzieci, przy współudziale szkół i organizacji społecznych. Powołanie Oddziału Wojewódzkiego TPD w Koszalinie poprzedzone było zebraniem Komitetu Organizacyjnego w dniu 8 września 1950 r. Ze wspomnień ówczesnego sekretarza Zarządu TPD Gabriela Bielawowskiego wynika, że komitet ten stanowili: Leon Kukulski, Edward Janiuk, Regina Pieniążek, Krystyna Harężówna, Józefa Gonerowa.

W okresie tzw. pierwszych kroków w działalności TPD duże zaangażowanie wykazali członkowie w odległych wioskach i osiedlach, którzy - będąc zdani na własne siły - wytrwale działali, organizując: ogniska przedszkolne, dziecińce wiejskie, place gier i zabaw, wycieczki, imprezy wczasowe, niosąc pomoc materialną dzieciom i ich rodzinom. Do najbardziej aktywnych członków należeli m.in.: Wanda Rzeźnicka w Worowie, Maria Kotlewska w Bielkowie, Zofia Czajkowa w Mścicach, Ewa Paśnik w Tychowie, Maria Narożna w Czeszeniewie, Fryderyka Swiręcz w Sporym.

W swych wspomnieniach Gabriel Bielawowski wymienił również najbardziej aktywnych przedstawicieli Zarządów TPD w Koszalińskiem. W latach pięćdziesiątych należeli do nich:

Antoni Jaciubek i Marian Stacki - w Białogardzie,

Mikołaj Turkiewicz - w Bytowie,

Michalina Wiącek, Kazimierz Chudy - w Drawsku Pomorskim,

Tadeusz Perednia, Czesław Kuiński, Zbigniew Ciechanowski - w Koszalinie,

Marian Jakimiak, Elżbieta Piotrowska - w Kołobrzegu,

Ignacy Stankiewicz - w Miastku,

Jadwiga Rutkowska, Bolesław Wyszyński - w Słupsku,

Jan Buraczy - w Sławnie,

Irena Komisarczyk, Jan Florecki - w Szczecinku,

Kazimierz Ślusarek, Antonina Karkosza - w Świdwinie,

Alfons Lewandowski, Bolesław Mojnarowicz - w Wałczu,

Leon Horst, Bronisław Płaczek - w Złotowie.

W latach 1950-1952 w województwie koszalińskim istniało i niosło pomoc opuszczonym i potrzebującym dzieciom 29 kół wiejskich TPD oraz 42 koła miejskie. Ich rozwój organizacyjny na terenie Pomorza Środkowego uważano za niedostateczny w stosunku do potrzeb. Miały na to wpływ dwa czynniki: brak rąk do pracy oraz mentalność ludzi pochodzących z różnych regionów Polski. Towarzystwo Przyjaciół Dzieci współdziałało z Kołami Gospodyń Wiejskich, np.: w Cieszeniewie - powiat Świdwin, w Bielkowie powiat Koszalin, w Trzesiece - powiat Szczecinek, w Biskupicy - powiat Człuchów.

W Koszalińskiem, w omawianym okresie nastąpił gwałtowny rozwój przedszkoli, szczególnie na wsiach w momencie tworzenia i rozbudowywania spółdzielni produkcyjnych. W okresie pilnych prac polowych (sianokosów, żniw, wykopków) każdego roku prowadzono średnio: w powiecie koszalińskim - 65 dziecińców, w powiecie złotowskim - 18 dziecińców, w powiecie bytowskim - 11 dziecińców, w powiecie człuchowskim -8 dziecińców, w powiecie słupskim - 10 dziecińców. Oddział TPD w Ko- 
szalinie współpracował również przy budowie ośrodka sportowo-wypoczynkowego na Górze Chełmskiej, udzielał stałej pomocy materialnej pięciu rodzinom, dwoje dzieci umieścił w Domu Dziecka, a matce postarał się o pracę. Prowadził akcje uświadamiające wśród rodziców.

Jednak na skutek decyzji władz państwowych TPD zostało postawione w stan likwidacji. Począwszy od 1950 r., gdy państwo przejęło zadania związane z opieką nad dzieckiem, znacznie zmniejszyła się również działalność PCK w tym zakresie. Przy Zarządzie Wojewódzkim PCK w Koszalinie powstała Komisja Opieki Społecznej, która przygotowywała młodzież szkolną w zakresie działalności opiekuńczej. Patronatem PCK objętych było wówczas 5 domów opiekuńczych dla osób starszych i 6 domów dziecka na terenie powiatów: Koszalin, Świdwin, Białogard, Słupsk, Bytów. Wspólnie z Towarzystwem do Walki z Gruźlicą prowadzono zakrojoną na szeroką skalę akcję profilaktyki i zwalczania tej groźnej choroby.

Komisja Opieki Społecznej organizowała akcje dożywiania dzieci lub akcje szklanka mleka w szkołach, organizowała wyjazdy dzieci biednych na kolonie letnie, przekazywała odzież i pomoce szkolne dla dzieci z rodzin patologicznych.

Okres drugiej połowy lat pięćdziesiątych i początku lat sześćdziesiątych był okresem stabilizacji organizacyjnej Towarzystwa Przyjaciół Dzieci, zwłaszcza w oddziałach powiatowych, co w dużej mierze zdecydowało o poszerzeniu i pogłębieniu działalności opiekuńczo-wychowawczej. Ogółem w latach 1956-1961 w Koszalińskiem funkcjonowało 101 kół z liczbą 2526 członków, a w roku 1961 - 132 koła z liczbą 3011 członków ${ }^{23}$.

Bardzo aktywną działalność przejawiały koła wiejskie:

- Koło Przyjaciół Dzieci w Trzesiece - powiat Szczecinek rozpoczęło swą działalność od organizacji ogniska przedszkolnego, a w okresie letnim każdego roku prowadziło dzieciniec dwuturnusowy,

- koło w Bielkowie - powiat Koszalin prowadziło ognisko przedszkolne, przeprowadziło niwelację terenu pod plac zabaw, zakupiło w nadleśnictwie drewno na słupki do ogrodzenia tego placu; prowadziło stałą akcję wycieczkową dla dzieci oraz utrzymywało stały kontakt z Kołem Przyjaciół Dzieci i Młodzieży przy Domu Kultury w Koszalinie; z jego inicjatywy zorganizowano i prowadzono przez okres dwóch lat Uniwersytet Powszechny dla rodziców,

- koło w Cieszeniewie zdobyło własny lokal dla ogniska przedszkolnego, zorganizowało i wyposażyło plac zabaw dla dzieci; należy nadmienić, że plac zabaw dla dzieci Koła Przyjaciół Dzieci w Cieszeniewie był pierwszym placem zabaw dla dzieci w środowisku wiejskim na terenie województwa koszalińskiego; organizowało również pomoc doraźną dla dzieci z rodzin będących w trudnej sytuacji materialnej,

- koło w Biskupicy - powiat Człuchów prowadziło takie same akcje, jak inne koła wiejskie, a poza tym organizowało akcje dożywiania dzieci podczas zimy.

${ }^{23}$ ATPD w Koszalinie, Dokumentacja walnych zebrań Zarządu Wojewódzkiego TPD z lat 1950-1965, s. $4-5$. 
Do najprężniej działających wiejskich ośrodków TPD należały w latach 1956-1961 koła w: Mścicach - pow. Koszalin, Strzelinku - pow. Słupsk, Nadarzycy - pow. Wałcz, Wyszewie - pow. Koszalin ${ }^{24}$.

Aktywną działalność przejawiały również miejskie Koła TPD. Świadczą o tym przykłady akcji prowadzonych przez te koła:

- koło przy szkole ćwiczeń przy Osiedlu Polanowskim w Sławnie otworzyło place gier i zabaw; udzielało pomocy materialnej, organizowało imprezy noworoczne, prowadziło świetlicę dla 45 dzieci zaniedbanych i opóźnionych w nauce,

- koło w Sławnie przy ul. Bieruta 80 oprócz wymienionych wyżej charakterystycznych dla wszystkich kół działań, opiekowało się dziećmi przewlekle i ciężko chorymi,

- koło przy Ośrodku Zdrowia w Polanowie organizowało badania dzieci, pogadanki z rodzicami z zakresu ochrony zdrowia, organizowało wystawy dotyczące tej tematyki.

Do szczególnie prężnie działających miejskich ośrodków TPD należały koła w: Koszalinie, Słupsku, Szczecinku, Białym Borze.

$\mathrm{Na}$ terenie Okręgu Koszalińskiego zorganizowano dwie Poradnie Społeczno-Wychowawcze TPD:

- w Koszalinie została otwarta w dniu 1 września 1960 r.,

- w Słupsku zaczęła funkcjonować z dniem 1 kwietnia $1961 \mathrm{r}$.

Prowadziły one działalność opartą na stałej współpracy z różnymi instytucjami specjalistycznymi, organizacjami, placówkami i zakładami wychowawczymi. Spełniały doniosłą rolę w badaniu sytuacji dziecka w rodzinie pod względem opiekuńczo-wychowawczym, badaniu przyczyn trudności i niepowodzeń szkolnych oraz udzielaniu pomocy w nauce. Zajmowały się dziećmi, które zostały zgłoszone do badań przez Koła Przyjaciół Dzieci, rodziców, szkoły, a także instytucje i organizacje społeczne, Milicję Obywatelską i sądy dla nieletnich.

W 1961 r. poradnia w Koszalinie obejmowała opieką 186 dzieci oraz prowadziła trzy punkty wyrównawcze przy szkołach podstawowych dla dzieci opóźnionych i mających trudności w nauce. W tym samym czasie poradnia w Słupsku miała pod opieką 55 dzieci i prowadziła jeden punkt wyrównawczy ${ }^{25}$.

Oprócz TPD podobną działalność prowadzili działacze Polskiego Czerwonego Krzyża, a Towarzystwo Burs i Stypendiów w dalszym ciągu udzielało pomocy niezamożnej kształcącej się młodzieży.

Następny, dziesięcioletni okres (lata 1962-1972) poświęcony był porządkowaniu głównych kierunków opieki nad dzieckiem. Wydano szereg dokumentów regulujących funkcjonowanie różnych form opieki nad dzieckiem, usprawniono system doskonalenia kadr zatrudnionych w opiece nad dzieckiem, organizowano kursy i konferencje poświęcone wymianie doświadczeń i gromadzeniu materiałów metodycznych. Decydujące znaczenie dla rozwoju opieki nad dzieckiem w tym czasie miała ustawa z 15 lipca $1961 \mathrm{r}$.

\footnotetext{
24 Ibidem, s. 10 .

25 Ibidem, s. 11.
} 
W województwie koszalińskim w dalszym ciągu TPD wnosiło znaczący wkład w funkcjonowanie opieki nad dzieckiem. Można tak sądzić na podstawie danych pochodzących z dokumentacji Zarządu Wojewódzkiego TPD ${ }^{26}$.

Tabela. Zestawienie form działalności TPD w latach 1962-1965

\begin{tabular}{|l|r|r|r|r|}
\hline \multicolumn{1}{|c|}{ Formy działań } & 1962 & 1963 & 1964 & 1965 \\
\hline Poradnie społeczno-wychowawcze & 2 & 2 & 2 & 2 \\
Świetlice & 1 & 4 & 4 & 6 \\
Place zabaw & 26 & 36 & 39 & 45 \\
Przedszkola społeczne & 4 & 7 & 5 & 5 \\
Ogniska przedszkolne & 57 & 74 & 112 & 124 \\
Kolonie wypoczynkowe & 2 & 2 & 2 & 2 \\
Półkolonie letnie i zimowe & 2 & 2 & 7 & 10 \\
\hline Dziecińce wiejskie & 24 & 30 & 30 & 34 \\
\hline
\end{tabular}

Źródło: opracowanie własne na podstawie danych Archiwum Towarzystwa Przyjaciół Dzieci w Koszalinie.

Do końca 1970 r. liczba dziecińców wiejskich TPD wzrosła o 60\%, a ognisk przedszkolnych o 80\%. Biorąc pod uwagę liczebność kół TPD, to w roku 1966 w miastach województwa koszalińskiego przybyło w porównaniu z poprzednimi latami 30 kół, a na wsiach 45. W 1967 roku liczba kół wiejskich wzrosła o 51, a w 1968 r. w porównaniu z 1967 r. przybyło 6 kół w miastach i 36 na wsiach.

Duże znaczenie w opiece nad dziećmi, w organizowaniu im czasu wolnego oraz udzielaniu pomocy w nauce miały świetlice prowadzone przez TPD w miastach: w Stupsku przy ulicy Długiej, w Kołobrzegu przy ul. Dworcowej, w Koszalinie przy ul. Hibnera i na Osiedlu Władysława IV, w Szczecinku przy ul. 1 Maja.

Na przełomie lat 1969/1970 w dalszym ciągu pod patronatem TPD powstawały dziecińce i świetlice wiejskie oraz place gier i zabaw: w Zalesiu - pow. Złotów, w Lubuczewie - pow. Słupsk, w Wierciszewie - pow. Koszalin, w Bolkowie - pow. Białogard, w Zakrzewie - pow. Złotów (również półkolonia dla dzieci).

W tym okresie akcją letnią objętych było 33480 dzieci, w tym 375 przebywało na koloniach wypoczynkowych, 149 na koloniach zdrowotnych, 1754 na półkoloniach, a pozostałe miały zorganizowane wczasy w mieście ${ }^{27}$. Wszystkie te działania prowadziło Towarzystwo Przyjaciół Dzieci.

\footnotetext{
${ }^{26}$ ATPD w Koszalinie znajduje się w siedzibie Zarządu - ul. Piłsudskiego 11-15.

${ }^{27}$ Dane pochodzą z dokumentacji walnych zebrań Zarządu Wojewódzkiego TPD, ATPD w Koszalinie, ul. Piłsudskiego 11-15.
} 
Każdego roku do Domu Wczasów Dziecięcych w Soli k/Krakowa wysyłano 120 dzieci z rodzin źle sytuowanych i zagrożonych wychowawczo na 6-tygodniowy pobyt na kolonii zdrowotnej.

W końcu lat sześćdziesiątych pomocą doraźną objętych zostało 1026 rodzin. Udzielono pomocy 3085 dzieciom w formie opłat za wyżywienie i pobyt w internacie, zakupu podręczników i przyborów szkolnych oraz uzupełnienia odzieży.

Początek lat siedemdziesiątych był okresem dalszego doskonalenia różnych form działania i współpracy z władzami i placówkami oświatowo-wychowawczymi, okresem dynamicznego rozwoju różnych form społecznej działalności placówek sezonowych, stałych i specjalistycznych.

Towarzystwo Przyjaciół Dzieci miało dobrze rozbudowaną sieć należycie funkcjonujących oddziałów. Pod koniec omawianego okresu zestawienie liczby kół oraz ich członków przedstawiało się następująco:

Oddział w Koszalinie - 80 kół, 4562 członków,

Oddział w Słupsku - 61 kół, 1649 członków,

Oddział w Złotowie - 60 kół, 1512 członków,

Oddział w Szczecinku - 45 kół, 1278 członków,

Oddział w Człuchowie - 39 kół, 547 członków,

Oddział w Sławnie - 37 kół, 1022 członków.

Szczególnie wyróżniającymi się w swej działalności miejskimi placówkami TPD w 1975 roku były:

Koło w Białogardzie przy ul. Nowotki,

Koło w Drawsku Pomorskim przy ul. Synów Pułku,

Koło w Koszalinie przy ulicy Kaszubskiej oraz przy ul. Jana z Kolna,

Koło w Złotowie przy Złotowskiej Spółdzielni Mieszkaniowej,

Koło w Słupsku przy ul. Długiej i na Osiedlu Zatorze,

Koło w Ryczewie przy ul. Garncarskiej,

Koło w Wałczu przy ul. Żeromskiego,

Koło w Miastku przy ul. Szewskiej.

Wyróżniającymi się w zakresie opieki nad dzieckiem wiejskimi kołami TPD w tym samym okresie były:

Koło w Modrzejewie - pow. Bytów,

Koło w Bobolicach - pow. Koszalin,

Koła w Wartkowie i Wrzosowie - pow. Kołobrzeg,

Koło w Józefowie - pow. Złotów,

Koło w Malechowie - pow. Sławno,

Koła w Lubieszewie i Ostrowicach - pow. Drawsko,

Koła w Warblewie i Głobinie - pow. Słupsk,

Koło w Chwiramiu - pow. Wałcz.

W działaniach na rzecz opieki nad dzieckiem szczególne zasługi położyli: Gabriel Bielawowski, Alfons Prondziński, Kazimierz Chudy, Feliks Sander, Stanisław Uciński, Stefan Dębski, Edwin Mańczyk, Ludomir Gałkowski, Jan Micyk, Zygmunt Maj, 
Czesław Kuiński, Eugenia Sobczyk, Stanisław Brzeziński, Barbara Szymak, Kazimierz Frąckowski, Andrzej Początek ${ }^{28}$.

W Koszalińskiem, zgodnie z założeniami polityki opiekuńczej państwa, zwrócono uwagę na wzmocnienie podstaw funkcjonowania rodzinnych form opieki nad dzieckiem. Zaczęły powstawać zbiorcze szkoły gminne. Opracowano i wdrożono koncepcje szkoły środowiskowej. Rozpoczęto fundowanie książeczek mieszkaniowych dla wychowanków opuszczających domy dziecka. Działalność taką prowadziły zakłady pracy, jednostki wojskowe, spółdzielnie mieszkaniowe itd.

\section{Podsumowanie}

Proces tworzenia i organizowania systemu oświatowo-wychowawczego na Pomorzu Środkowym w latach 1945-1975 charakteryzowała duża dynamika rozwoju instytucji szkolnych i opiekuńczo-wychowawczych. Praca na tym terenie była szczególnie trudna, ponieważ wiązała się z długotrwałym procesem asymilacji do nowych warunków przybyłej z różnych stron ludności, z dużymi zniszczeniami wojennymi, z brakiem poczucia stabilizacji i bezpieczeństwa.

Nowa polityka opiekuńcza opierała się na następujących założeniach:

- problemy opieki nad dzieckiem nie mogą być rozwiązywane dopiero w chwili pojawienia się, lecz konieczne jest przesunięcie akcentów na szeroką dziedzinę działania profilaktycznego,

- należy rozwinąć wielki ruch społeczny, który byłby czynnikiem mobilizującym i inspirującym powszechną akcję opiekuńczą,

- musi istnieć koordynacja wysiłków podejmowanych przez poszczególne resorty w zakresie opieki nad dzieckiem,

- należy zapewnić wysoki poziom kadry pracowników w placówkach.

W latach 1962-1975 dokonano wnikliwej analizy funkcjonowania internatów, burs szkolnych i domów dziecka. Rozwinięto szkolną opiekę (ośrodki szkolno-wychowawcze, półinternaty) dla tych, którzy z różnych względów nie mieli opieki wychowawczej $\mathrm{w}$ domu.

Terenowe oddziały administracji szkolnej podjęły prace zmierzające do tworzenia poradni wychowawczych - placówek oświatowo-wychowawczych opartych na jednolitym statucie. W tym zakresie na zlecenie Ministerstwa Oświaty prowadziło je Towarzystwo Przyjaciół Dzieci.

Polityka opiekuńcza państwa w dalszym ciągu opierała się na doraźnych działaniach, do tej pory nie opracowano jednolitego, całościowego, racjonalnego programu, zbyt mało uwagi poświęcano działaniom profilaktycznym w zakresie opieki nad dzieckiem.

${ }^{28}$ Wszystkie dane pochodzą z dokumentacji walnych zebrań Zarządu Wojewódzkiego TPD z lat 1949-1975. Wybór osób dokonany został na podstawie przemówienia byłego sekretarza TPD Gabriela Bielawowskiego przygotowanego z okazji 50-lecia działalności TPD. 
Od początku lat siedemdziesiątych zaczęto wprowadzać modyfikację organizacji życia i działalności placówek opiekuńczo-wychowawczych i poszukiwać nowych form wychowania opiekuńczego. Pracowano również nad wzmocnieniem funkcji opiekuńczo-wychowawczej szkoły i wdrażaniem koncepcji otwartej szkoły środowiskowej w mieście i na wsi.

\section{Bibliografia}

D. Apanel, Instytucjonalna opieka catkowita nad dzieckiem na Pomorzu Środkowym w latach 1945-1975, Wydawnictwo Pomorskiej Akademii Pedagogicznej, Słupsk 2006.

S. Lisowski, Metody działalności karytatywnej. Analiza zagadnienia na tle działalności Caritasu w Polsce w latach 1945-1950, „Studia Teologiczne” 1976.

O. Terlecki, Najkrótsza historia drugiej wojny światowej, Kraków-Wrocław 1984.

J. Wojtyniak, H. Radlińsk, Sieroctwo. Zasięg i wyrównanie, Łódź 1946.

Zagrożone dzieciństwo. Rodzinne i instytucjonalne formy opieki, red. M. Kolankiewicz, Warszawa 1998.

\section{The role of non-governmental organizations in child care in Middle Pomerania in the years 1945-1975 - an outline of the problem}

\section{Summary}

The activity of NGOs in Middle Pomerania after the end of WWII to the times of political changes and economic transition can be divided into two characteristic and distinct stages, i.e. one until the year 1950, and the other covering the years from 1950 to the political breakthrough of 1989.

In the first stage, the activities directed at well-being of the child and the family were mostly undertaken by the Worker's Society of the Friends of Children (Polish: RTPD), the Peasants' Society of the Friends of Children (ChTPD), Polish Red Cross (PCK), Central Committee for Welfare (CKOS), the Polish Women League and the Society for Pupils' Hostels and Scholarships.

The above organizations kept sanitary and medical facilities, educational and care institutions, including children's homes, correctional houses, preventoria, day care rooms, pupils' hostels and boarding houses, crèches and kindergartens, ran summer camps for children, field kitchens, hospitals, night shelters, training workshops, catering establishments, outpatient clinics, ambulance services, health care establishments and mother and child care units.

According to the data available at the archives of the Society of the Friends of Children in Koszalin covering the years 1946-1949, included in annual reports of RTPD and ChTPD, these organizations provided care to about 8,300 children.

CKOS attended to about 43,500 individuals, including children. The organization distributed clothing, footwear and medicine obtained within the framework of the structural assistance from the UN.

According to data obtained from annual reports of the Polish Red Cross in Koszalin for the years 1945-1955, assistance was rendered to about 120,000 individuals. 
Towards the end of the first stage of the activity of NGOs, due to the changes in welfare policy of the country, many organizations were dissolved or had to change their profile. The most successful organization in the second stage was the Society of the Friends of Children. The Society provided social and vocational counseling services, ran day care rooms, kindergartens, village crèches, summer camps for children and summer and winter play centres. The available reports of regional TPD in Middle Pomerania for the years 1950-1975, state that there were 322 local associations of TPD in the region, amounting to 10,570 members.

Work of NGOs in Middle Pomerania was basically determined by the long-run process of assimilation of the population that came from other regions of the country to new living conditions, by considerable war damages and lack of stability and security. 